\title{
A new specimen of Xiphiorhynchus cf. X. aegyptiacus (Istiophoriformes, Xiphioidei, Xiphiidae) and Billfish Diversity in the Oligocene of South Carolina
}

\author{
William N. McCuen ${ }^{1, \star}$, Aika S. Ishimori ${ }^{1}$, and Robert W. Boessenecker ${ }^{1,2}$ \\ ${ }^{1}$ College of Charleston, Charleston, SC, 29424, USA; mccuennn@g.cofc.edu; ishimorias@g.cofc.edu; \\ boesseneckerrw@cofc.edu \\ ${ }^{2}$ University of California Museum of Paleontology, University of California, Berkeley, CA 94720
}

\begin{abstract}
A partial billfish rostrum from the Chandler Bridge Formation (early Chattian, Oligocene) near Ladson, South Carolina, U.S.A., is described and identified as Xiphiorhynchus cf. X. aegyptiacus. The angle of taper, depth to width ratio of the cross section, and other morphological features (including dorsolateral grooves and a planoconvex cross-section), indicate that this specimen (and an earlier published specimen) is closest in morphology to X. aegyptiacus from the Eocene Birket Qarun and Qasr el Sagha formations of Egypt. This confirms the presence of a second xiphiid in the Chandler Bridge Formation besides the well-documented giant swordfish $X$. rotundus. This is an unusual example of two Xiphiorhynchus species existing in sympatry, and strongly contrasting morphologies and morphometrics may point to niche partitioning between the two forms. The occurrence of specimens strongly resembling $X$. aegyptiacus in the western Atlantic also further substantiates past arguments that easy dispersal across the Atlantic was possible for this genus, and, by extension, that it shared the open-sea, migratory epipelagic lifestyle of modern swordfish. Moreover, the Chandler Bridge Formation boasts the most diverse billfish assemblage in the world, including Xiphiorhynchus cf. X. aegyptiacus, X. rotundus, an early istiophorid, and 4-7 species of blochiid billfish in the genera Aglyptorhynchus and Cylindracanthus.
\end{abstract}

\section{INTRODUCTION}

The swordfish family Xiphiidae has a poorly understood evolutionary history. The sole extant species, Xiphias gladius, is uncommon as a fossil; all other xiphiid remains fall into the Eocene-Oligocene genus Xiphiorhynchus (Fierstine 2006). Ten species of Xiphiorhynchus have been described from the Atlantic and former Tethys and Paratethys, along with a possible record from Antarctica (Agassiz 1844; Cope 1869; van Beneden 1871; Woodward 1901; Leriche 1909; Weiler 1929; Fierstine and Applegate 1974; Fierstine and Pfeil 2009). Possible Pliocene remains from the southeastern Pacific (Peru) have also been suggested to represent Xiphiorhynchus (De Muizon and Devries 1985). Despite this diversity and wide distribution, Xiphiorhynchus is poorly understood; five species are known only from holotype fragments, and only a handful of specimens include any postcrania whatsoever; moreover, holotypes for two species are lost (Fierstine 2006).
Here we describe a new specimen (CCNHM-4406) of Xiphiorhynchus from the upper Oligocene Chandler Bridge Formation of South Carolina. Together with previously published remains, it clarifies the identification of another xiphiid taxon (Xiphiorhynchus sp.) in the region, enhancing our knowledge of the family's history while raising questions about its ecology and evolution.

\section{MATERIALS AND METHODS}

Identification Methods: Thanks to compilation of extensive morphometric data on billfish rostra by species, it is possible to identify even very fragmentary rostra. We used the datasets of Fierstine and Starnes (2005) and Fierstine and Weems (2009) to evaluate CCNHM-4406 in terms of angle of taper ( $\alpha$, the angle between lateral margins) and cross-sectional depth to width ratio $(\mathrm{D} / \mathrm{W})$; ratios involving the complete rostrum could not be used because the distal portion of our specimen is missing. 
Institutional Abbreviations: CCNHM, Mace Brown Museum of Natural History, at the College of Charleston, Charleston, South Carolina, USA; ChM, Charleston Museum, Charleston, South Carolina, USA.

\section{SYSTEMATIC PALEONTOLOGY}

\section{Class ACTINOPTERYGII Cope, 1887}

Division TELEOSTEI, Müller, 1844

Order ISTIOPHORIFORMES Betancur-R et al. 2013

Suborder XIPHIOIDEI Rafinesque, 1815

Family XIPHIIDAE Rafinesque, 1815

Subfamily XIPHIORHYNCHINAE Regan, 1909

Genus Xiphiorhynchus van Beneden, 1871

Xiphiorhynchus cf. X. aegyptiacus

Locality and Geological Setting: Chandler

Bridge Formation, Chattian (late Oligocene), McKewn

Subdivision, North Charleston, Dorchester County, South Carolina, U.S.A.

The Chandler Bridge Formation is typically $1-1.5$ meters thick and exposed in the vicinity of Summerville, South Carolina. It is an unlithified, noncalcareous, and patchy deposit consisting of four beds: olive phosphatic silt (bed 0 ), light yellowish brown silty quartz sandstone (bed 1), brown phosphatic sandstone (bed 2), and light olive gray clayey quartz sandstone (bed 3; Katuna et al. 1997). Deposition of the Chandler Bridge Formation was initiated in a marine shelf environment, transitioning to foreshore and estuarine conditions and then a mixed estuarine/ fluvial environment (Katuna et al. 1997). Microfossils further support this assessment; marine dinoflagellates are common in the lower beds, only to be replaced by pollen and plant debris in bed 2 (Katuna et al. 1997). However, marine vertebrate fossils are common throughout the unit, particularly beds 0-2 (Katuna et al. 1997; Cicimurri and Knight 2009), suggesting continuous marine deposition. The Chandler Bridge formation unconformably overlies the lower Oligocene Ashley Formation, which represents a deeper water (mid-outer shelf) environment but bears an essentially similar fossil fauna (Fierstine and Weems 2009). CCNHM-4406 was collected from an unusual section of the Chandler Bridge Formation exposed within two stormwater pond excavations in the McKewn Homes subdividision in Ladson, South Carolina. This section included a 1 $m$ thick typical section of the Chandler Bridge Formation (including beds $1-2$, but lacking beds 0 and 3) overlain by $1-1.5$ meters of unconsolidated, massively bedded, fine to very fine grained (and occasionally silty) quartz sand with scattered vertical cylindrical burrows and $1-6 \mathrm{~cm}$ diameter discoidal quartz pebbles. This upper sandy unit is in turn overlain by the Pleistocene Ten Mile Hill beds (Weems and Lemon 1984). The upper sandy unit entirely lacks calcareous material like the remaining Chandler Bridge Formation and is decidedly less fossiliferous than typical beds 1-2 at the same locality; however, fossil marine vertebrate taxa typical for the Chandler Bridge Formation occur within this unit, including Carcharhinus gibbesi, Physogaleus aduncas, Hemipristis serra, Plinthicus stenodon, Rhinoptera sp., Cylindracanthus, Carolinachelys, and the giant dolphin "Genus Y" (Tab. 1). However, some unusual taxa typical for younger Miocene deposits also occur, including teeth resembling Galeocerdo 'casei', Carcharhinus leucas, and eurhinodelphinid and squalodelphinid odontocetes.

This upper sandy unit differs from the OligoceneMiocene Edisto Formation and Parachucla Formation by consisting entirely of clean, quartzose sandstone rather than calcarenite and notably lacks a basal phosphatic bonebed. All Oligocene-Miocene formations in the Charleston Embayment are expressed with a basal phosphatic bonebed and disconformity (Weems and Lemon 1984; Weems et al. 2014). Instead, bed 2 of the Chandler

Table 1. Faunal list for the upper sandy unit of the Chandler Bridge Formation

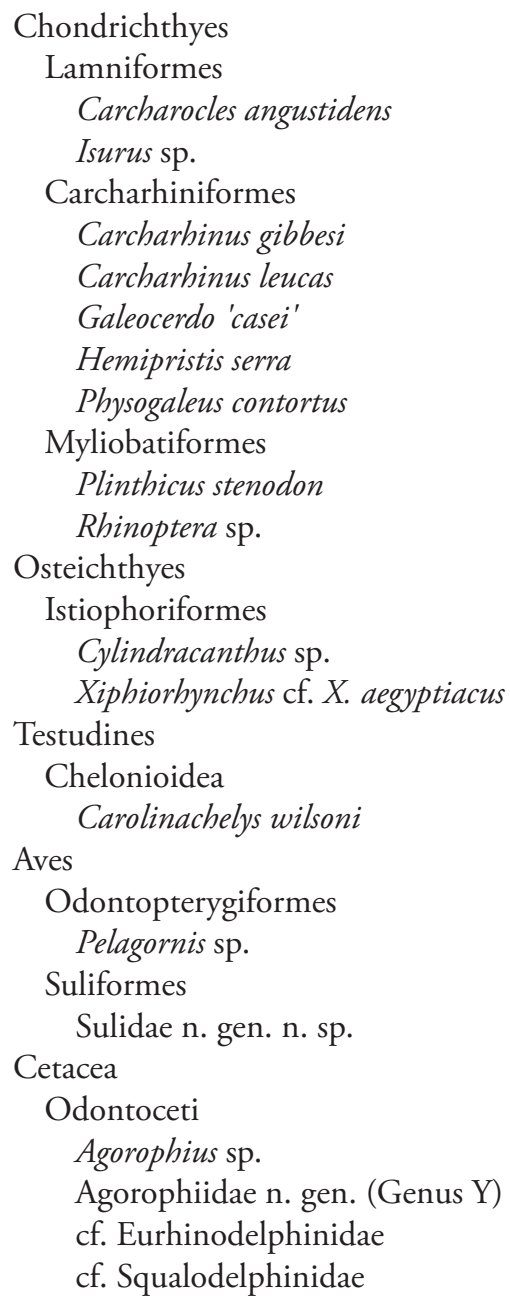


Bridge Formation smoothly grades into the upper sandy unit without a clear erosional surface mantled with a phosphate pebble and fossil bearing lag deposit like other boundaries. Therefore, at present, it is most parsimonious to consider this bed to belong to the Chandler Bridge Formation, which is already known to be heterogeneous with lateral changes in lithology and varies from exposure to exposure by the presence or lack of particular beds (chiefly bed 0 and bed 3; Sanders et al. 1982; Katuna et al. 1997). At this locality, this upper unit appears to grade laterally into a blueish gray siltstone resembling bed 3 - although we hesitate to identify this upper stratum as bed 3 (or a new bed) for the time being. Regardless, this lateral facies change from the upper stratum to bed 3 strongly suggests that the two are equivalent in age.

The Chandler Bridge Formation has yielded dinoflagellates corresponding to zones NP 24-25 (29.6-23.1 Ma) and $87 \mathrm{Sr} / 86 \mathrm{Sr}$ ratios from fossil oysters (bed unknown; 24.7-24.5 Ma). In accordance with $87 \mathrm{Sr} / 86 \mathrm{Sr}$ dates of 23.5 Ma from the overlying Edisto Formation, an age of 24.7-23.5 Ma is assigned to the Chandler Bridge Formation (Boessenecker and Fordyce 2016). It is unclear whether these dates apply readily to this upper unit as this layer may be younger than the typical beds. The Edisto and Parachucla formations do not crop out extensively and are rarely identified in subsurface auger holes (Weems et al. 2014), and only one small exposure of each unit is present in the Charleston embayment, 20 and $28 \mathrm{~km}$ (respectively) due west of this locality. The stratum overlying this upper sandy unit is Pleistocene. For the time being, no evidence suggests that this upper unit is younger than Oligocene and, pending further study, a latest Oligocene age is assigned. We note that matrix associated with two skulls of the archaic dolphin Agorophius sp. reported from a nearby exposure (Coosaw Preserve Subdivision) by Boessenecker and Geisler (2018) match this lithology and reassign the stratum that these specimens were collected from (bed 2) to this upper sandy unit.

Description: Billfish rostra, exemplified by the dramatic 'sword' of swordfish, marlin etc., consist of extremely elongate, fused premaxillae that bifurcate posteriorly before meeting the rest of the skull while tapering to a sharp point distally (in istiophorids, but not xiphiids, the prenasals also extend into the rostrum's proximal portion). Hollow longitudinal nutrient canals also run the length of a xiphioid rostrum, the number and arrangement of which varies among species and families (Fierstine 2006). CCNHM-4406 (Fig. 1A-C; Tab. 2) is a partial rostrum, acutely triangular in dorsal and ventral views, approximately $11.5 \mathrm{~cm}$ long. The cleft between the posterior ends of the premaxillae (where they diverge proximally) is wider and extends farther forward on the ventral side than the dorsal
Table 2. Mean angle of taper $(\alpha)$ and depth to width (D/W) ratios of specimens of Xiphiodei after Fierstine and Voigt (1996) and Fierstine and Starnes (2005), with measurements for CCNHM-4406. ( $\alpha$ values for extant species are unpublished and unavailable.)

\begin{tabular}{lll}
\hline Specimen type & $\mathrm{D} / \mathrm{W}$ & $\alpha$ \\
\hline $\begin{array}{l}\text { CCNHM-4406 } \\
\text { Xiphiorhynchus }\end{array}$ & \\
$\quad$ cf. X. aegyptiacus & 0.53 & 10.3 \\
$X$. aegyptiacus & 0.45 & 11.5 \\
$X$. eocaenicus & 0.62 & 16.0 \\
$\begin{array}{l}\text { X. elegans } \\
\text { X. kimblalocki }\end{array}$ & 0.63 & 5.0 \\
$\begin{array}{l}\text { X. rotundus } \\
\text { X. priscus (range) }\end{array}$ & 0.82 & 10.0 \\
ChM PV8317 & 0.84 & 19.0 \\
$\begin{array}{l}\text { (Xiphiorhynchus indet.) } \\
\text { Istiophorus platypterus } \\
\text { (mean and range) }\end{array}$ & $0.69-0.79$ & $3.0-12.0$ \\
$\begin{array}{l}\text { Tetrapturus albidus } \\
\text { (mean and range) }\end{array}$ & $0.68(0.58-0.78)$ & - \\
$\begin{array}{l}\text { Makaira nigricans } \\
\text { (mean and range) }\end{array}$ & $0.62(0.56-0.66)$ & - \\
$\begin{array}{l}\text { Xiphias gladius } \\
\text { (mean and range) }\end{array}$ & $0.70(0.59-0.80)$ & - \\
\hline & $0.34(0.29-0.39)$ & - \\
\hline
\end{tabular}

side. On both sides, the cleft extends farther anteriorly along the midline as a shallow groove, with the groove on the dorsal surface deeper than on the ventral side. Both grooves gradually shallow and terminate before reaching the distal end of the specimen. Breakage at both ends of the specimen reveals the longitudinal nutrient canals typical for billfish rostra (Fierstine and Voight 1996), but their full number and pattern are not evident, seemingly owing to suboptimal preservation and the natural obscurity of some canals that occurs in some specimens (compare cross sections from Fierstine and Weems 2009:figs. 25D, E, 26D; Fierstine and Starnes 2005:fig. 4). Almost the entire dorsal and lateral portions have been broken off the hollow proximal section of the right premaxilla. On the left side, enough of the dorsolateral surface is preserved that a wide, shallow groove that reaches to the anterior tip of the fossil is apparent. The ventral surface is much more flattened than the dorsal, giving a planoconvex cross-section (Fig. 1D). CCNHM-4406 was found to have an $\alpha$-value of $10.3^{\circ}$, and a $\mathrm{D} / \mathrm{W}$ value of 0.53 (Tab. 2).

Identification and Comparisons: Despite including most of the proximal portion of the rostrum, CCNHM-4406 shows no suturing to indicate extension of the prenasals into the posterior half of the rostrum (characteristic of Istiophoridae, see above, Fierstine 2006). It also 


\section{A.}

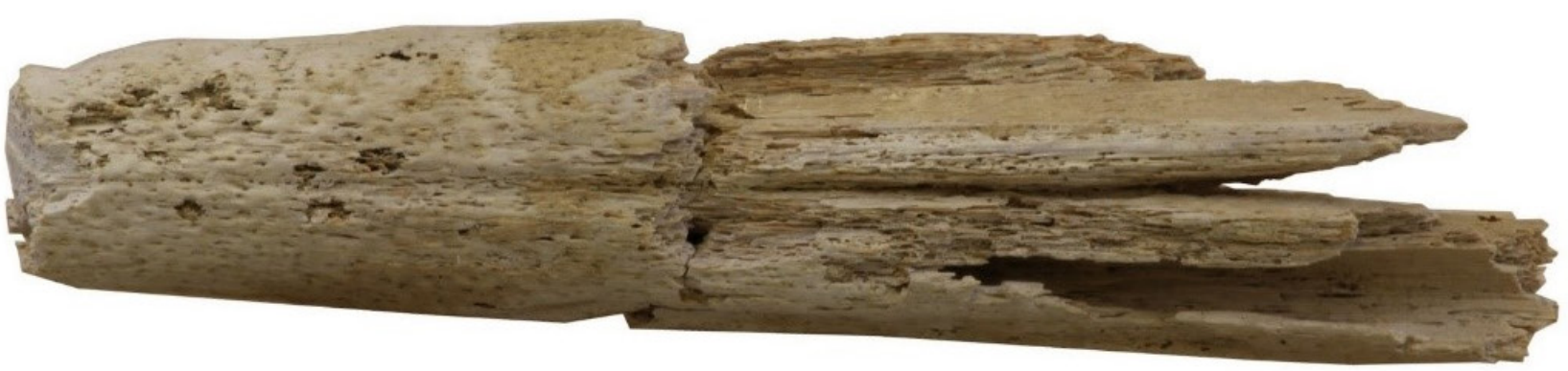

B.
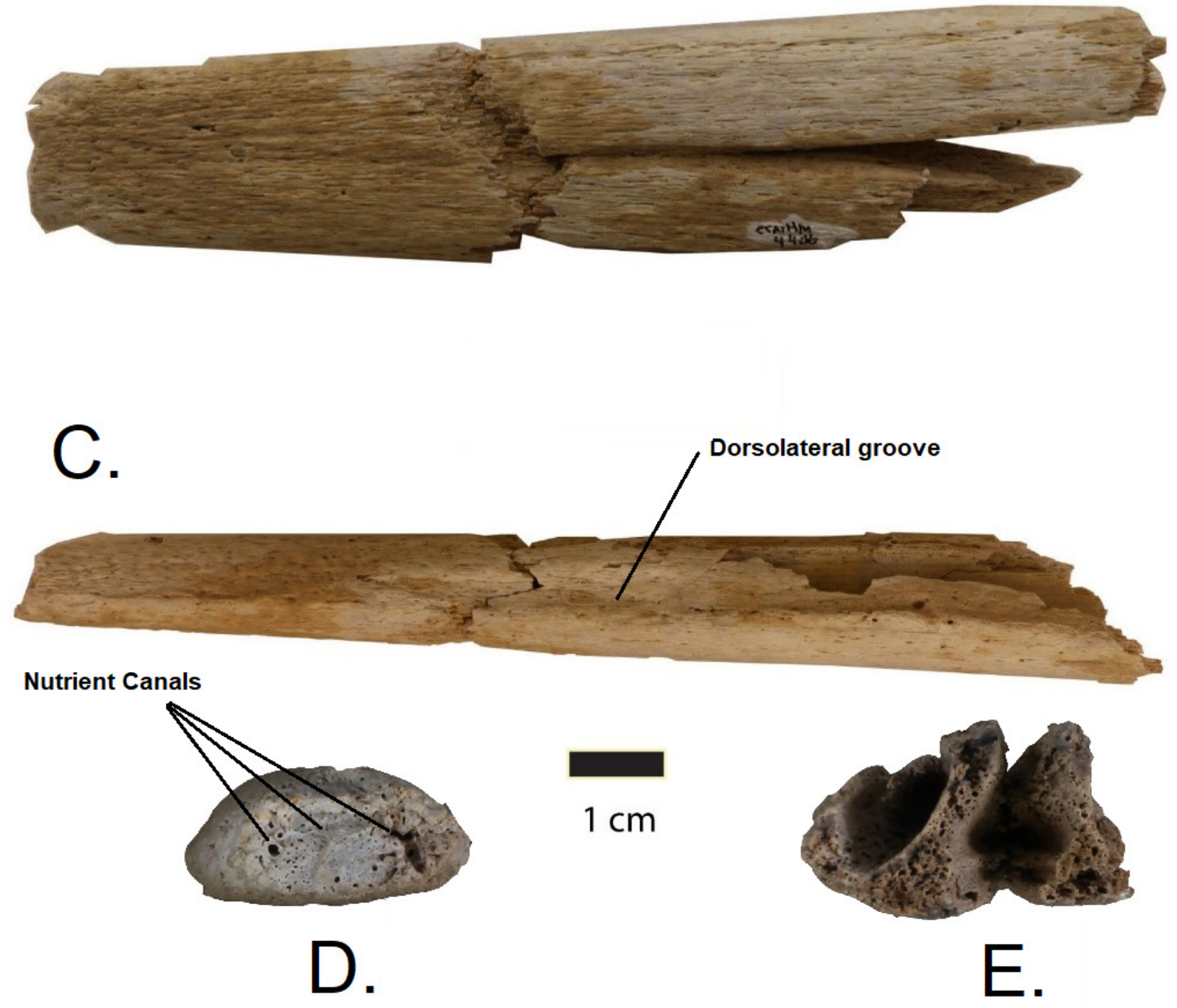

Dorsolateral groove
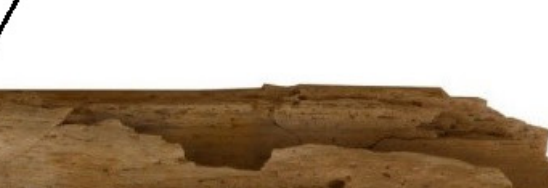
has a more dorsoventrally flattened cross-section (lower $\mathrm{D} / \mathrm{W}$ ratio) than the round proportions found in that family, although less flattened than the modern swordfish (Xiphias gladius, see Table 2).

CCNHM-4406 is also distinct from Xiphiorhynchus rotundus $\left(\mathrm{D} / \mathrm{W}=0.84, \alpha=19.0^{\circ}\right.$, see Table 2$)$, a xiphiid well-documented from the Chandler Bridge Formation by Fierstine and Weems (2009). In addition to distinct proportion values, the adult size of $X$. rotundus (up to around 5 $\mathrm{m}$ in total length, based on estimates from isolated vertebrae; Fierstine and Weems 2009) is also much greater than this individual (although CCNHM-4406 may be a juvenile, considering its small size and relatively poorly ossified, porous bone texture).

However, Fierstine and Weems also reported another, very different specimen of Xiphiorhynchus from the Chandler Bridge, ChM PV8317, a rostrum only slightly larger than CCNHM-4406. With a D/W of 0.53 and $\alpha$ of $10.3^{\circ}$, this specimen not only has similar proportions to CCNHM-4406, it also shares the same planoconvex cross section. They noted close similarity of that specimen in these features to the geochronologically older species Xiphiorhynchus aegyptiacus from the late Eocene of Egypt (Tab. 2), but hesitated to refer it to that species owing to poor preservation, difference in time (7-10 my), and geographic separation between localities (Fierstine and Weems 2009). Besides the traits they noted, X. aegyptiacus and ChM PV8317 also share a shallow groove on each dorsolateral surface of the rostrum (noted above for CCNHM-4406, compare rostra from Fierstine and Weems 2009:fig. 26A; Fierstine and Gingerich 2009:fig. 2B). In view of these similarities, it is likely that ChM PV8317 and our specimen, CCNHM-4406, are conspecifics of a poorly understood billfish form from the late Oligocene of South Carolina, possibly a geochronologically late occurrence of $\mathrm{X}$. aegyptiacus (representing a major range and temporal extension for that species), or an as-yet unnamed close relative. We therefore identify CCNHM-4406 as Xiphiorhynchus cf. X. aegyptiacus, noting that more complete specimens are needed to further clarify species-level identification.

\section{DISCUSSION}

\section{Ecology and Distribution of Xiphiorhynchus:}

CCNHM-4406 and ChM PV8317 may extend the known geographic and geochronologic range of $X$. aegyptiacus, raising implications for the ecology of Xiphiorhynchus. Fierstine and Starnes (2005) used the occurrence of Xiphiorhynchus sp. cf. $X$. eocaenicus in North America (X. eocaenicus was previously only documented from Britain) to argue for a transatlantic distribution of that species, and, by extension, that species of Xiphiorhynchus shared pelagic, migratory cosmopolitan habits with modern swordfish. The presence of $X$. aegyptiacus in North America would also support this conclusion. However, most Xiphiorhynchus species have very limited, rarely overlapping spatiotemporal ranges (Agassiz 1844; Cope 1869; van Beneden 1871; Woodward 1901; Leriche 1909; Weiler 1943; Fierstine and Applegate 1974; Fierstine 2006; Fierstine and Pfeil 2009; Fierstine and Weems 2009). This could argue against the South Carolina specimens being $X$. aegpytiacus, but this temporal and spatial restriction very well may be an artifact of taxonomic oversplitting, or the sheer rarity (Fierstine 2006) of Xiphiorhynchus remains (causing most species to only be known from very few localities).

Interestingly, Xiphiorhynchus aegyptiacus and this extremely similar North American form show some of the lowest known $\mathrm{D} / \mathrm{W}$ values in the genus, coming closest to those of modern Xiphias (Tab. 2). This would have affected the function of the rostrum as a hunting weapon, the increasingly popular primary explanation for rostral elongation in xiphioids. Rostral morphology and the exact behavioral tactics involved in its employment show variations between extant species (Habegger et al. 2015, Habegger et al. 2020, Hansen et al. 2020). Biomechanics studies (Habegger et al. 2015, Habegger et al. 2020) seem to indicate that rostral flattening in living swordfish helps facilitate rapid lateral slashes to stun or even severely damage small, schooling prey fish, a behavior supported by finds of fish cut in half in swordfish stomachs. The combination of thinness in lateral view with a relatively much greater width would streamline the rostrum for such motion, while still ensuring flexural stiffness, strength against lateral stresses, and a narrow surface of impact for maximum prey damage. In contrast to the more swordfish-like morphology found in $X$. aegyptiacus, $X$. rotundus has much higher $\mathrm{D} / \mathrm{W}$ values, comparable to modern Istiophoridae (Tab. 2). The same studies on extant billfish rostral function concluded that the round cross-section of istiophorid rostra is better optimized for multi-directional (as opposed to strictly lateral) swiping, as well as stabbing motions. Both tactics are supported by field observations of istiophorid hunting and stomach contents (Habegger et al. 2015, 2020). Considering the role of the rostrum in foraging, it is very possible that the markedly different morphologies in these two forms of Xiphiorhynchus reflect differences in hunting tactics as well, perhaps even analogous to those between their modern relatives.

\section{Billfish Ecology and Diversity in the Oligocene} of South Carolina: The successive Ashley and Chandler Bridge formations of South Carolina represent the richest locality (in terms of diversity) in the world for fossil billfish. Besides Xiphiorhynchus cf. X. aegyptiacus, and 
the giant swordfish Xiphiorhynchus rotundus, Fierstine and Weems (2009) noted that these rocks have yielded at least three (possibly as many as six) species of the large blochiid Aglyptorhynchus, the small purported blochiid Cylindracanthus, and fragments of the earliest definite istiophorid. The next most speciose billfish assemblage is that of the lower Eocene London Clay (UK), with six species (Friedman et al. 2015). It is unclear whether this unparalleled diversity of fossil billfish reflects time averaging of fossiliferous shallow marine deposits or genuine diversity. In parallel, unusually speciose assemblages of cetaceans and sea turtles (Boessenecker and Geisler 2018, and references therein; R.W. Boessenecker pers. observ.) are reported from these Oligocene strata. Billfish remains, even if just isolated fin rays, are frequently encountered in the Ashley and Chandler Bridge formations (R.W. Boessenecker, pers. observ.), suggesting not just high diversity, but high abundance in the area as well. Many of these billfish fossils (for instance, CCNHM-4406) are preserved in shallow marine deposits (see also Fierstine and Weems 2009), which is contrary to expectations if ancient billfish were deep-water pelagic migrants. However, other authors note that carcasses drifting with the currents, movement of remains long distances in the stomach contents of large predators, and even rostra breaking off in the bodies of impaled animals and being transported thereafter have been observed for modern billfish and cannot be totally discounted for fossils unless they are fairly complete and well-articulated (Fierstine and Starnes 2005).

Although time-averaging and even long-distance postmortem transport may help explain billfish richness and diversity in these rocks, other possible factors include niche partitioning or habitat segregation. If postmortem transport was important to Ashley and Chandler Bridge formation taphonomy, it raises the possibility of billfish being transported from slightly different, nearby habitats to a single final resting place. However, particularly if the billfishes of this assemblage shared, at least to some extent, the wide-roaming, epipelagic habits of their modern counterparts, as argued above, it is likely they overlapped and competed directly. In this scenario, fine niche partitioning would explain the diversity observed. Against this backdrop, the differences between forms of Xiphiorhynchus noted above take on a new interest, as does the bizarre morphology of Aglyptorhynchus. Unlike any extant billfish, Aglyptorhynchus had a mobile rostrum, which, complemented by its equally elongate mandible, would have allowed a uniquely wide gape. Moreover, at least one of the species present here, $A$. robustus, had a ball-and-socket articulation between the first vertebra and the occipital condyle, possibly related to hunting strategy and otherwise almost unknown in teleosts (Fierstine and Weems 2009).
Like Xiphiorhynchus, the Aglyptorhynchus species in this assemblage show variations in rostral morphology (Fierstine and Weems 2009) that could also have ecological relevance (e.g., higher $\mathrm{D} / \mathrm{W}$ values in $A$. palmeri than in $A$. alsandersi). For now, detailed interpretations of such data must remain speculative, but we hope some of the above points regarding contrasting morphologies may help guide future studies of the factors that have shaped xiphioid diversity. The Oligocene rocks of South Carolina have proven an excellent source of billfish fossils, outstanding in the world for species richness; future research here promises to continue to clarify the murky evolutionary history of billfishes.

\section{ACKNOWLEDGEMENTS}

This study would not have been possible without the generosity of S. Hildenbrandt, who donated the specimen. Thanks to B. Doster and DR Horton Construction for locality access. We thank S. Boessenecker (CCNHM) for providing access to specimens under her care. Finally, we are also grateful to M. Manuelo, who was involved in the early research work.

\section{LITERATURE CITED}

Agassiz, L. 1833-1944. Recherches sur les Poissons fossiles. Neuchatel, Switzerland: Petitpierre. DOI 10.5962/bhl.title.4275

Betancur-R, R., R.E. Broughton, E.O. Wiley, K. Carpenter, J.A. López, C. Li, N.I. Holcroft, D. Arcila, M. Sanciangco, J.C. Cureton II, F. Zhang, T. Buser, M.A. Campbell, J.A. Ballesteros, A. Roa-Varon, S. Willis, W. Borden, T. Rowley, P.C. Reneau, D.J. Hough, G. Lu, and T. Grande. 2013. The tree of life and a new classification of bony fishes. PLoS Currents 5. DOI 10.1371/currents.tol.53ba26640df0ccaee75bb165c8c26288

Boessenecker, R.W., and J.H. Geisler. 2018. New records of the archaic dolphin Agorophius (Mammalia: Cetacea) from the upper Oligocene Chandler Bridge Formation of South Carolina, USA. PeerJ 6:e5290. DOI 10.7717/peerj.5290

Boessenecker, R.W., and R.E. Fordyce. 2017. A new eomysticetid from the Oligocene Kokoamu Greensand of New Zealand and a review of the Eomysticetidae (Mammalia, Cetacea). Journal of Systematic Palaeontology 15:429-469. DOI 10.1080/14772019.2016.1191045

Cicimurri, D.J., and J.L. Knight 1997. Late Oligocene sharks and rays from the Chandler Bridge Formation, Dorchester County, South Carolina, USA. Acta Palaeontologica Polonica 54:627-647. DOI 10.4202/app.2008.0077

Cione, A.L., M.A. Reguero, and D.H. Elliot. 2001. A large osteichthyan vertebra from the Eocene of Antarctica. Neues Jahrbuch fur geologie und Palaontologie - Monatshefte 9: 543-552. DOI 10.1127/njgpm/2001/2001/543

Cope, E.D. 1869. Descriptions of some extinct fishes previously unknown. Proceedings of the Boston Society of Natural History $12: 310-317$. 
Cope, E.D. 1887. Geology and paleontology. American Naturalist 21:1014-1019.

Fierstine, H.L. 2006. Fossil history of billfishes (Xiphioidei). Bulletin of Marine Science 79:433-453.

Fierstine, H. L., and S.P. Applegate. 1968. Billfish remains from southern California with remarks on the importance of the predentary bone. Bulletin of the Southern California Academy of Sciences 67:29-39.

Fierstine, H.L., and P.D. Gingerich. 2009. A second and more complete rostrum of Xiphiorhynchus aegyptiacus Weiler, 1929, (Perciformes: Xiphioidei: Xiphiidae: Xiphiorhynchinae), from the Birket Qarun Formation, upper Eocene, Egypt. Journal of Vertebrate Paleontology 29:589-593. doi: $10.1671 / 039.029 .0207$

Fierstine, H. L., and F. Pfeil. 2009. Xiphiorhynchus haeringensis, a new genus and species of billfish (Perciformes, Xiphioidei, Xiphiidae, Xiphiorhynchinae) from Bad Haring, Tyrol, Austria, lower Oligocene (NP 22). Palaeo Ichthyologica 11:5-42.

Fierstine, H.L., and J.E. Starnes. 2005. Xiphiorhynchus cf. X. eocaenicus (Woodward, 1901), (Scombroidei: Xiphiidae: Xiphiorhynchinae) from the middle Eocene of Mississippi, the first transatlantic distribution of a species of Xiphiorhynchus. Journal of Vertebrate Paleontology 25:280-287. DOI 10.1671/0272-4634(2005)025[0280:XCXEWS]2.0.CO;2

Fierstine, H.L., and N.L. Voigt. 1996. Use of rostral characters for identifying adult billfishes (Teleostei: Perciformes: Istiophoridae and Xiphiidae). Copeia 1996:148-161. DOI $10.2307 / 1446950$

Fierstine, H.L., and R.E. Weems. 2009. Paleontology of the Oligocene Ashley and Chandler Bridge formations of South Carolina, 4: Analysis and new records of billfishes (Perciformes: Xiphioidei). Palaeo Ichthyologica 11:43-88.

Friedman, M., H.T. Beckett, R.A. Close, and Z. Johanson. 2016. The English Chalk and London Clay: Two remarkable British bony fish Lagerstätten. Geological Society, London, Special Publications 430:165-200. DOI 10.1144/SP430.18

Habegger, M.L., M.N. Dean, J.W.C. Dunlop, G. Mullins, M. Stokes, D.R. Huber, D. Winters, and P.J. Motta. 2015. Feeding in billfishes: inferring the role of the rostrum from a biomechanical standpoint. The Journal of Experimental Biology 218: 824-836. DOI 10.1242/jeb.106146

Habegger, L, P. Motta, D. Huber, D. Pulaski, I. Grosse, and E. Dumont. 2020. Feeding biomechanics in billfishes: investigating the role of the rostrum through finite element analysis. The Anatomical Record 303:44-52. DOI 10.1002/ar.24059

Hansen, M.J., S. Krause, M. Breuker, R.H.J.M. Kurvers, F. Dhellemmes, P.E. Viblanc, J. Müller, C. Mahlow, K. Boswell, S. Marras, P. Domenici, A.D.M. Wilson, J. E. Herbert-Read, J.F. Steffensen, G. Fritsch, T. B. Hildebrandt, P. Zaslansky, P. Bach,
P.S. Sabarros, and J. Krause. 2020. Linking hunting weaponry to attack strategies in sailfish and striped marlin. Proceedings of the Royal Society B 287. DOI 10.1098/rspb.2019.2228

Katuna, M.P., J.H. Geisler, and D.J. Colquhoun. 1997. Stratigraphic correlation of Oligocene marginal marine and fluvial deposits across the middle and lower coastal plain, South Carolina. Sedimentary Geology 108:181-194. DOI 10.1016/ S0037-0738(96)00053-X

Leriche, M. 1909. Note preliminaire sur des poissons nouveaux de l'Oligocene Belge. Bulletin de la Société Belge de Géologie, de Paléontologie et d'Hydrologie, Procés-Verbaux 22:378-384.

Muizon, C. de, and T.J. Devries. 1985. Geology and paleontology of late Cenozoic marine deposits in the Sacaco area (Peru). Geologische Rundschau 74:547-567. DOI 10.1007/ BF01821211

Müller J. 1844. Über den Bau und die Grenzen der Ganoiden und über das natürliche System der Fische. PhysikalischMathematische Abhandlungen der koniglichen Akademie dei Wissenschaften zu Berlin 1845:117-216.

Regan, C.T. 1909. On the anatomy and classification of the scombroid fishes. Annals and Magazine of Natural History 8:66-75. DOI 10.1080/00222930908692547

Rafinesque, C.S. 1815. Analyse de la nature, ou tableau de l'univers et des corps organises, Palerme, 224 pp.

Sanders, A.E. 1980. Excavation of Oligocene marine fossil beds near Charleston, South Carolina. National Geographic Society Research Reports 12:601-621.

van Beneden, P. J. 1871. Recherches sur quelques poissons fossiles de Belgique. Bulletin de l'Académie Royale des Sciences, des Lettres et des Beaux-Arts de Belgique 31:493-518.

Weems, R.E., and E.M. Lemon. 1984. Map of the Stallsville quadrangle, Dorchester and Charleston counties, South Carolina. U.S. Geological Survey Quadrangle Map Q-1581.

Weems, R.E., L.M. Bybell, L.E. Edwards, W.C. Lewis, and J.M. Self-Trail. 2016. Stratigraphic revision of the Cooper Group and the Chandler Bridge and Edisto formations in the Coastal Plain of South Carolina. South Carolina Geology 29:1-24.

Weems, R.E., W.C. Lewis, and E.M. Lemon, Jr. 2014. Surficial geologic map of the Charleston region, Berkeley, Charleston, Colleton, Dorchester, and Georgetown Counties, South Carolina. U.S. Geological Survey Open File Report 2013-1030. U.S. Geological Survey Geologic Quadrangle Map GQ-1581. DOI 10.3133/ofr20131030

Weiler, W. 1943. Ein schwertfisch-Rostrum aus dem mitteloligozän Ungarns. Zeitschrift der Deutschen Geologischen Gesellschaft 95:214-217.

Woodward, A.S. 1901. Catalogue of the Fossil Fishes in the British Museum (Natural History) Volume 4, London, Order of the Trustees. $636 \mathrm{p}$. 